\title{
Gambaran kadar limfosit pada pekerja bangunan
}

\author{
${ }^{1}$ Dhea Tiara \\ ${ }^{2}$ Murniati Tiho \\ ${ }^{2}$ Yanti M. Mewo
}

${ }^{1}$ Kandidat Skripsi Fakultas Kedokteran Universitas Sam Ratulangi Manado

${ }^{2}$ Bagian Biokimia Fakultas Kedokteran Universitas Sam Ratulangi Manado Email: Dheatiara13@gmail.com

\begin{abstract}
Humans spend most of their time on activities. In this modern era, due to increasing competitiveness, everyone is demanded to work harder, causing an ineffective time management. The increase of activity can affect health if not accompanied with adequate rest. The increase of activity can affect physiological function that can cause stress to the body. When stress occured, sympathic nervous and adrenal gland will affect the body's immune system, one of them is lymphoid tissue. Physical activity with moderate to high intensity can cause a change of lymphocyte level in the body. Construction workers are one of the kind of high intensity physical activity. This study aimed to discover the description of lymphocyte level on construction workers. This study was conducted on August 2016 to December 2016. This study is a descriptive study with cross sectional design and the sampling technique was total sampling, 30 respondents were participating. The study result showed that lymphocyte level on 17 respondents $(56,7 \%)$ was normal, 4 respondents $(13,3 \%)$ had an elevated lymphocyte level and 9 respondents $(30 \%)$ had a depressed lymphocyte level. Conclusion: This study result that most of the respondents had a normal lymphocyte level.
\end{abstract}

Keywords: lymphocyte level, construction worker, physical activity.

\begin{abstract}
Abstrak: Manusia menghabiskan sebagian besar waktu untuk beraktivitas. Di era modern ini, karena tingkat persaingan semakin tinggi, setiap orang dituntut untuk bekerja lebih keras, sehingga menyebabkan orang tidak dapat mengatur waktu secara efektif. Peningkatan aktivitas dapat mempengaruhi kesehatan jika tidak disertai dengan istirahat yang cukup. Peningkatan aktivitas fisik dapat mempengaruhi fungsi fisiologi tubuh yang akhirnya akan menimbulkan stres pada tubuh. Pada saat terjadi stres, saraf simpatik dan kelenjar adrenal akan mempengaruhi sistem imun, salah satunya adalah jaringan limfoid. Aktivitas fisik dengan intensitas sedang sampai berat dapat menyebabkan perubahan jumlah limfosit dalam tubuh. Pekerja bangunan merupakan salah satu aktivitas fisik dengan intensitas berat. Penelitian ini bertujuan untuk mengetahui gambaran kadar limfosit pada pekerja bangunan. Penelitian ini dilakukan pada bulan Agustus 2016 sampai dengan Desember 2016. Penelitian ini merupakan penelitian deskriptif dengan desain penelitian cross-sectional dan pengambilan sampel secara total sampling dengan 30 orang responden. Dari hasil penelitian didapatkan bahwa gambaran kadar limfosit pada pekerja bangunan terdapat 17 responden $(56,7 \%)$ memiliki kadar limfosit normal, 4 responden $(13,3 \%)$ memiliki kadar limfosit meningkat dan 9 responden $(30 \%)$ memiliki kadar limfosit menurun. Simpulan: Sebagian besar responden memiliki kadar limfosit normal.
\end{abstract}

Kata kunci: kadar limfosit, pekerja bangunan, aktivitas fisik. 
Dalam kehidupan, manusia menghabiskan sebagian besar waktu (kurang lebih 8590\%) untuk beraktivitas. ${ }^{1}$ Pada era modern ini, tingkat persaingan semakin tinggi, sehingga setiap orang dituntut untuk bekerja lebih keras dalam mempertahankan kehidupannya yang menyebabkan mereka tidak mengatur waktu secara efektif, sehingga aktivitas fisik yang dijalankan melampaui batas ketahanan tubuh yang akhirnya dapat berdampak pada kesehatan. ${ }^{2}$

Menurut World Health Organization (WHO), aktivitas fisik merupakan gerakan tubuh yang dihasilkan oleh otot rangka yang memerlukan pengeluaran energi. Aktivitas fisik dibagi menjadi tiga golongan yaitu ringan, sedang, dan berat. Buruh bangunan merupakan pekerjaan yang dikategorikan sebagai aktivitas fisik intensitas sedang sampai berat. ${ }^{1}$

Intensitas dan beban kerja yang berlebih, tentu saja memerlukan jumlah energi yang lebih besar. Apabila tidak diimbangi dengan waktu istirahat yang cukup, maka dapat mempengaruhi atau mengganggu fungsi fisiologi tubuh yang akhirnya akan menimbulkan stress. ${ }^{2}$

Pada saat terjadi stres, saraf simpatik dan kelenjar adrenal akan mempengaruhi sistem imun, yaitu jaringan limfoid, termasuk thymus, limfe, dan kelenjar getah bening. Senyawa endogen yang dilepaskan selama stress dapat meningkatkan atau menekan fungsi sistem imun. Sistem imun melibatkan berbagai jenis sel dengan fungsi saling terkait. ${ }^{3}$

Sistem imun tubuh terdiri dari dua komponen utama, yaitu limfosit B dan limfosit T. Limfosit B terutama berasal dari sel sumsum tulang. Limfosit $\mathrm{T}$ berasal dari timus. Limfosit $\mathrm{B}$ bertanggung jawab membentuk antibodi humoral dalam darah yang juga dikenal sebagai imunoglobulin. Sel limfosit $\mathrm{T}$ berperan dalam berbagai respon imunologi seluler, misalnya reaksi hipersensitifitas, pertahanan terhadap sel ganas dan banyak virus. ${ }^{4}$

Berdasarkan hasil penelitian pengaruh aktivitas fisik intensitas sedang terhadap kadar limfosit darah yang dilakukan oleh Irianti dkk pada 15 sampel yang melakukan aktivitas naik turun bangku (NTB) disimpulkan bahwa aktivitas fisik intensitas sedang akan meningkatkan rata - rata presentasi limfosit. $^{5}$

Penelitian yang dilakukan oleh Harahap pada 21 sampel yang melakukan aktivitas fisik maksimal ditemukan bahwa terjadi peningkatan kadar limfosit yang signifikan setelah melakukan aktivitas fisik maksimal. $^{6}$

Berdasarkan penelitian-penelitian tersebut, maka peneliti tertarik melakukan penelitian untuk melihat gambaran jumlah kadar limfosit pada pekerja buruh bangunan di Fakultas Kedokteran Unsrat.

\section{METODE PENELITIAN}

Penelitian ini bersifat deskriptif dengan pendekatan cross sectional study. Penelitian ini dilaksanakan mulai bulan Agustus 2016 hingga Desember 2016 di area pembangunan gedung kuliah Fakultas Kedokteran Universitas Sam Ratulangi. Sampel dalam penelitian ini berjumlah 30 orang yang sesuai kriteria inklusi yaitu pekerja bangunan dengan aktivitas fisik intensitas berat di Fakultas Kedokteran Universitas Sam Ratulangi Bersedia mengikuti penelitian dengan mengisi dan menandatangani informed consent dan sehat. Metode pemilihan sampel menggunakan cara total sampling. Pemeriksaan kadar limfosit darah diambil melalui darah vena (fossa cubiti), responden tidak puasa. Sampel darah yang diperoleh dibawa ke laboratorium Kanaka dan diperiksa dengan menggunakan alat Sysmex XS-800i. Data diolah dengan menggunakan Microsoft Office Excel 2007.

\section{HASIL PENELITIAN}

Penelitian ini dilakukan di Fakultas Kedokteran Universitas Sam Ratulangi dengan tujuan untuk mengetahui gambaran kadar limfosit pada pekerja bangunan. Pemilihan sampel menggunakan metode total sampling didapatkan jumlah responden sebanyak 30 orang yang memenuhi kriteria inklusi. Responden semuanya berjenis kelamin laki-laki dan memiliki rentang usia 18-51 tahun. 
Berdasarkan hasil pemeriksaan yang telah dilakukan dengan menggunakan nilai rujukan dari Laboratorium Kanaka, kadar limfosit normal yaitu $25-40 \%$ jumlah seluruh kadar limfosit dari jumlah leukosit. Pada penelitian ini didapatkan lebih dari separuh responden $(56,7 \%)$ mempunyai jumlah limfosit normal. (Tabel 1).

Tabel 1. Distribusi responden berdasarkan kadar limfosit.

\begin{tabular}{ccc}
\hline Kadar limfosit (\%) & $(\mathbf{n})$ & $(\boldsymbol{\%})$ \\
\hline Normal $(25-40)$ & 17 & 56,7 \\
Meningkat $(>40)$ & 4 & 13,3 \\
Menurun $(<25)$ & 9 & 30 \\
\hline Total & $\mathbf{3 0}$ & $\mathbf{1 0 0}$ \\
\hline
\end{tabular}

\section{BAHASAN}

Berdasarkan hasil penelitian yang telah dilakukan, terdapat 4 orang $(13,3)$ dari 30 responden yang kadar limfosit meningkat $>40 \%$ dan terdapat 9 orang $(30 \%)$ yang kadar limfosit menurun $<25 \%$. Kadar limfosit pada 17 responden $(56,7)$ lainnya dalam keadaan normal yaitu dengan kadar $25-40 \%$.

Kadar limfosit dipengaruhi oleh aktivitas fisik, pengobatan, dan penyakit. Dimana kadar limfosit pada penelitian ini sebagian besar responden memiliki kadar limfosit yang berada dalam batas normal. Hal ini dikarenakan para responden tidak sedang menderita penyakit infeksi.

Limfosit merupakan jenis leukosit agranulosit yang memiliki berbagai peran fungsional berhubungan dengan reaksi imun terhadap serangan mikroorganisme, makromolekul asing, maupun sel- sel kanker. $^{7}$

Pada penelitian ini terdapat 9 orang (30\%) yang memiliki kadar limfosit menurun. Persentase limfosit dibawah kisaran normal dapat disebabkan oleh banyaknya limfosit yang sudah berada di jaringan.

Penurunan persentase limfosit dapat disebabkan adanya migrasi limfosit dari sirkulasi darah ke jaringan. ${ }^{8}$ Beban maksimal juga menyebabkan menurunnya produksi antibodi dan penurunan fungsi limfosit secara umum. ${ }^{9,10,11}$

Pada penelitian ini juga terdapat 4 orang $(13,3 \%)$ yang memiliki kadar limfosit meningkat. Persentase limfosit dapat meningkat akibat leukimia limfatik, infeksi mononukleus maupun infeksi virus. Peningkatan persentase limfosit dapat terjadi apabila ada kerusakan sel-sel pada jaringan atau organ tubuh yang mengharuskan adanya respon untuk Destruksi sel-sel yang mengalami kerusakan atau apoptosis. ${ }^{8}$

Aktivitas fisik dengan intensitas maksimal dan melelahkan dilaporkan justru dapat menyebabkan gangguan imunitas. ${ }^{12}$ Penelitian pada tikus putih setelah pemberian aktivitas fisik maksimal berupa renang sampai hampir tenggelam, ditemukan adanya peningkatan jumlah limfosit darah tikus putih. ${ }^{13}$

Penelitian yang dilakukan oleh Harahap pada 21 sampel yang melakukan aktivitas fisik maksimal ditemukan bahwa terjadi peningkatan kadar limfosit yang signifikan setelah melakukan aktivitas fisik maksimal. $^{6}$

Pada penelitian yang dilakukan Prima di Sumetera Barat pada tahun 2015 dengan subjek penelitian adalah 12 ekor mencit (Mus musculus) jantan yang dibagi menjadi dua kelompok. Kelompok I mencit dengan aktivitas fisik sedang dan kelompok II mencit dengan aktivitas fisik berat. Pada mencit kelompok I didapatkan kenaikan jumlah limfosit sebesar 35\% ( $\mathrm{P}=0,028)$ dan pada mencit kelompok II didapatkan kenaikan jumlah limfosit yang sangat tinggi yaitu sebesar $203 \%(P=0,028)$. Hal ini disebabkan karena pada aktivitas fisik berat akan menyebabkan trauma pada tubuh yang akan merangsang proliferasi dari limfosit. ${ }^{14}$

Terdapat kendala pada penelitian ini yaitu terdapat responden yang kurang dimana hanya 30 sampel yang bersedia menjadi subjek penelitian dari total sampling 47 sampel, karena 17 responden lain menolak untuk diambil darahnya, sehingga response rate dari penelitian ini ialah sebesar $60 \%$. 


\section{SIMPULAN}

Berdasarkan hasil penelitian kadar limfosit yang telah dilakukan pada pekerja bangunan dapat disimpulkan bahwa sebagian besar responden memiliki kadar limfosit normal.

\section{SARAN}

1. Untuk responden yang memiliki hasil kadar limfosit yang normal disarankan untuk mempertahankan kadar limfositnya dengan mengonsumsi makanan yang sehat serta menjaga gaya hidup sehat.

2. Untuk responden yang memiliki hasil kadar limfosit yang menurun, disarankan untuk menjaga sanitasi dan menjaga gaya hidup sehat untuk mencegah tertular penyakit.

3. Untuk responden yang memiliki hasil kadar limfosit yang meningkat disarankan untuk memperhatikan pola hidup dan istirahat yang cukup.

4. Pada penelitian selanjutnya disarankan untuk menambah jumlah responden dan dilakukan penelitian dengan jenis pekerjaan yang lebih bervariasi.

5. Dilakukan penelitian analitik yang membandingkan kadar limfosit sebelum dan sesudah aktivitas fisik berat.

\section{UCAPAN TERIMA KASIH}

Ucapan terima kasih disampaikan dr.Murniati Tiho, MKes, AIFO, dan dr. Yanti M. Mewo, MPdKed, pekerja bangunan, Laboratorium kanaka dan pada semua pihak yang telah menumbuhkan ide atau gagasan dalam pemikiran penulis sehingga penulis bisa menyelesaikan artikel ini.

\section{DAFTAR PUSTAKA}

1. Gibney MJ, Margetts BM, Kearney JM, Arab L. Gizi kesehatan masyarakat. Jakarta: EGC; 2009. p. 100-5

2. Luan, Yuan. Pengaruh hiperactivity sebagai penginduksi stres terhadap perubahan jumlah limfosit $b$. Tesis. Surabaya : Widya Mandala Catholic University; 2014.
3. Huether SE, McCance KL. Understanding pathophysiology. $3^{\text {th }}$ ed. Mosby Inc; 2004. p. 222-300.

4. Murray RK. Protein plasma \& immunoglobulin. Dalam: Murray RK, Granner DK, Rodwell VW, Editor. Biokimia Harper. Edisi ke 27. Pendit $\mathrm{BU}$, alih bahasa Indonesia. Wulandari $\mathrm{N}$, editor edisi bahasa Indonesia. Jakarta: penerbit buku kedokteran EGC; 2009. p. 616.

5. Irianti E. Pengaruh aktivitas fisik sedang terhadap hitung leukosit dan hitung jenis leukosit pada orang tidak terlatih. Medan: USU Repository; 2008.

6. Harahap Novita. Pengaruh aktivitas fisik maksimal terhadap jumlah dan hitung jenis leukosit pada mencit (Mus musculus L) jantan. Available from: http://repository.usu.ac.id/bitstream

7. Junqueira LC, Carneiro J. Histologi dasar: teks dan atlas. Edisi Kesepuluh. Jakarta: EGC; 2004. h. 220-33.

8. Widyastuti ND. Profil darah tikus putih wistar pada kondisi subkronis pemberian natrium nitrit. Jurnal Sain Veteriner. Desember 2013;31(2).

9. Maree G. Mucosal ommune responses and risk of respiratory illness in elite athlete. Exercise Immunology Review. 2000:1, 6.

10.Wood J, Lu Q, Lowder T. Exercise induced modulation macrophage function. Immunology and cell biology. 2000;78:545-53.

11. Keast D. Immune responses to overtraining and fatique. New York: Exercise And Immune Function CRC Pres. 1996.

12.Hartanti M, Pardede H, Kodariah R. Kadar immunoglobulin a dalam air liur atlet pasca pertandingan. Majalah Kedokteran Indonesia. 1999.

13.Jawi IM. Gambaran histologis lien dan jumlah limfosit darah tikus putih setelah overtraining. Bali: Ergonomics And Sport Physiology Seminar. 2001

14.Dwipa PI. Pengaruh aktivitas fisik berat terhadap hitung jumlah limfosit pada mencit (Mus musculus) [Thesis]. Padang: Universitas Andalas; 2015. 